\title{
A Rule-Based Parsing System for Encoding Kennicott's Collation of the Hebrew Bible
}

A Rule-Based Parsing System for Encoding Kennicott's

Collation

of the Hebrew Bible

\author{
Luigi Bambaci ${ }^{1}$
}

${ }^{1}$ University of Bologna

Department of Cultural Heritage

12 January 2020 
Introduction

Qohelet

Kennicott's work

Digitalization

Optical character recognition

The Context-free Grammar

The Visitor

TEl encoding

Stemmatic analysis 


\section{Qohelet: A Digital Scholarly Edition}

The parser is part of a $\mathrm{PhD}$ project devoted to the preparation of a digital scholarly edition of the biblical book of Qohelet

Goals of the edition

- Collatio: digitalization of readings

> Constitutio textus: critical text (eclectic edition)

$>$ Encoding according to the Text Encoding Initiative

A Rule-Based Parsing System for Encoding

Kennicott's

Collation of the Hebrew Bible

Qohelet

Kennicott's work

Digitalization

Optical character recognition

The Context-free Grammar The Visitor

TEl encoding

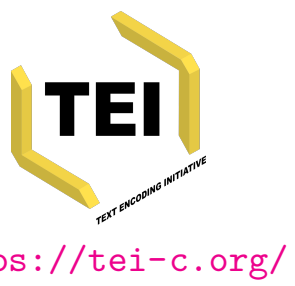




\section{Qohelet: A Digital Scholarly Edition}

\section{Goals of the parser}

- The parser is designed to encode the readings of Qohelet contained in medieval mss and printed editions as collated by Kennicott

- The encoding is used for quantitative analysis

- To identify stemmatic relationships

A Rule-Based Parsing System for Encoding

Kennicott's

Collation

of the Hebrew

Bible

Qohelet

Kennicott's work

Digitalization

Optical character

recognition

The Context-free Grammar

The Visitor

TEI encoding 


\section{Qohelet: A Digital Scholarly Edition}

Goals of the parser

- The parser is designed to encode the readings of Qohelet contained in medieval mss and printed editions as collated by Kennicott

- The encoding is used for quantitative analysis

- To identify stemmatic relationships

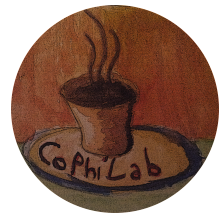

http://cophilab.ilc.cnr.it/
A Rule-Based

Parsing System for Encoding

Kennicott's

Collation

of the Hebrew

Bible

Qohelet

Kennicott's work

Digitalization

Optical character

recognition

The Context-free Grammar The Visitor

TEl encoding

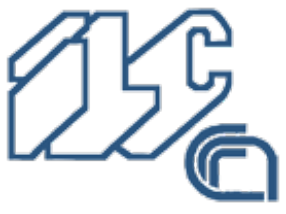

http://www.ilc.cnr.it/ 


\section{The book of Qohelet}

The book of Qohelet or Ecclesiastes is one of the books of the Hebrew Bible (V-III a.e.v.)

\section{Sources}

1. Direct sources: witnesses in Hebrew

- Qumran scrolls (II-I a.e.v.)

- Hebrew medieval manuscripts and printed editions

2. Indirect sources: ancient translations (Versions):

2.1 Primary translations (Hebrew source):

- Greek (Septuaginta, I-II e.v.)

- Syriac (Peshitta, II e.v.)

- Latin (Vulgata, Commentarius, IV e.v.)

- Aramaic (Targumim, VII e.v.)

2.2 Secondary translations (Greek source):

- Ethiopic (IV e.v.)

- Armenian (V e.v.)

- Syro-hexapla (VII e.v.)

-... 


\section{Medieval tradition: the XVIII c. collations}

Our access to medieval documentation is still mainly mediated by the works of B. Kennicott and G. B. De Rossi

\section{$\begin{array}{lllll}V & E & T & U & S\end{array}$}

T E S T A

$\begin{array}{lllllllll}\text { H } & \text { E } & \text { B } & \text { R } & \text { A } & \text { I } & \text { C } & \text { U } & \text { M }\end{array}$

C U M

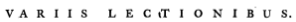

E D I D I T

B B N J A I N U S K E N I C O T T, S.T. P.

EDIS CHRISTI CANONICUS,

ET BIBLIOTHECARIUS RADCLIVIANUS.

TOMUS SECUNDUS.

O $\mathrm{X}$ O $\mathrm{N}$ I I,

E TYPOGRAPHEO CLARENDONIANO.

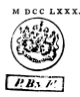

Kennicott, 1778

\section{VETERIS - TESTAMESTI}

EX IM ENSA

MSS. EDITORUMQ. CODICUM CONGERIE HAUSTAE

ET AD SAMAR. TEXTUM, AD VETUSTISS. VERSIONES.

AD ACCURATIOHes SACRAe CRITICAE fONTES AG LE\&E

EXAMINATAE

OPERA AC STUDIO

JOHANNIS BERN. DE-ROSSI S. T. D.

ET IN R: PARMENSI aCAD. LING. OR. PROFESS.

VOLUMEN III

ISAIAS, JEREMIAS, EZECHIEL, XII PROPHETAE MINORES, CANTICUM, RUTH, THRENI, ECCLESIASTES, ESTHER.

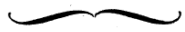

Veteum libroram fides de Hebratis relutuinibus examinanda est.

Hieron. Ep pist. ed Lüür.

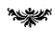

P A R M A E

EX REGIO TYPOGRAPHEO

cIJ. Iocc. $\mathrm{L} \times \times \times \mathrm{vI}$.

De Rossi, 1788

Kennicott's work
A Rule-Based Parsing System for Encoding

Kennicott's

Collation

of the Hebrew Bible

Introduction

Qohelet

Optical character

recognition

The Context-free Grammar

The Visitor

TEl encoding 


\section{Medieval tradition: the XVIII c. collations}

- Kennicott and De Rossi gathered thousands of variants from more than 1500 witnesses of the Hebrew Bible

$>$ Kennicott:

- 2 volumes, ca. 1800 pages

- 600 witnesses

- 1.500 .000 pieces of textual information (Barthélemy)

> The collations contain important text-critical and linguistic information about the history of the biblical text and Hebrew language in the Middle Ages

> No extensive collations have been planned since then

$>$ They are available only in a digitized format (.pdf) 


\title{
Qohelet according to Kennicott
}

A Rule-Based

Parsing System

for Encoding

Kennicott's

Collation

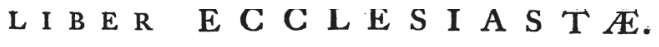

of the Hebrew

Bible

\author{
C A $\mathbf{P}$ U $\mathbf{T}$ I.
}

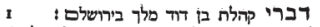

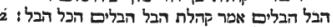

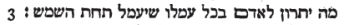

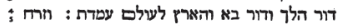

השפש ובא השמש ואל מקופו שראף זורח הרא

שם: הולד אל דרום וסובב אל צפון סובב 6

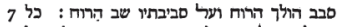

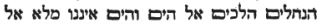

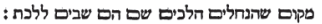

כל הדברים יגעים לא יוכל איש לדבר לא תשבע 8 לים

עין לראות ולא תשלא אזן משמע : פרז שהיה 9

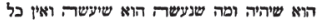

חדש תחר השמש : יש דבר שיאמר ראה זה 10

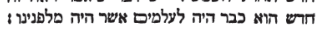

גו איו זכרון לראשנים וגם לאתרנים שיהיו לא 12 13

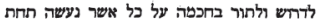

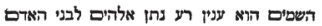

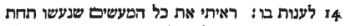

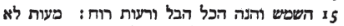

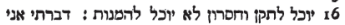

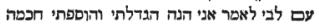
על כל אשר היר, לפגי על ירושלם ולבי רארד

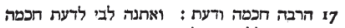
ודעת הללות ושכלות ידעהי שגם זה הוא לוא רעיון 18 רוח: כי ברב חכפה רב כעם ויוסיף דעת יוסיף רופו

טכאוב

VARIAS LECTIONES.

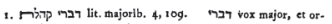
nata ; 136, 139- non major; 1, 2, 3, 14, 31, 57, 67, 82, 89, 93, 99, 100, 110, 1 19, 128, 130, 141, 144, 231, 237, 239, 270, 289. בירושלים . 57, 121. 107, 109, 152 - fup. raf. 139 - שירושים 76.

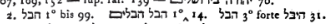

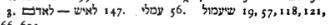
166,693 .

$166,172,173,176,188,191,196,21 i, 212,213,218 ; 224,226$, $227,228,231,239,240,245,252,253,260,275,384,680,693$. רי $22^{\circ}, 157-17$. $31,93,110,119,141,177,210$ $218,248,259,264,270,277,288 \mathrm{~T}, 300 \mathrm{~T}-1206{ }_{151}, 196$,

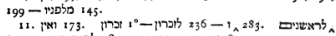

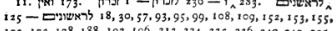
$172,173,178,188,192,196,213,224,235,236,240,249,252$, 


\section{Qohelet according to Kennicott}

A Rule-Based

Parsing System

for Encoding

Kennicott's

Collation

L I B E R E C C L E S I A S T E.

of the Hebrew

\section{A $\mathbf{P}$ U $\mathbf{T}$ I.}

דברי קהלת בן דוד מלך בירושלם:

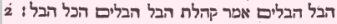

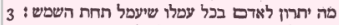

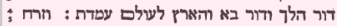

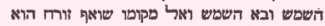

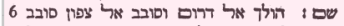

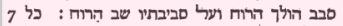

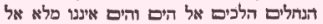

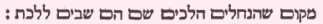

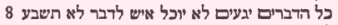

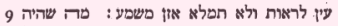

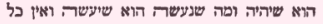

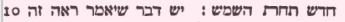

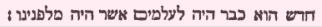

\section{VARIAS L E C T I O N E S.}

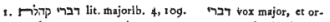
nata; 136, 139- non major; 1, 2, 3, 14, 31, 57, 67, 82, 89, 93, $99,100,110,119,128,130,141,144,231,237,239,270,289$.

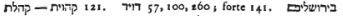
107, 109, 152 - fup. raf. $139-\square$ - 76.

2. הבל $1^{\circ}$ bis 99.0 . 31.

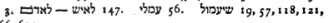
166,693 .
1ג 12

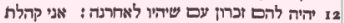

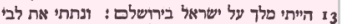
לדרוש ולתור בחכטה על כל אשר נעשה תחת למים

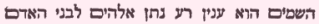

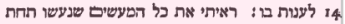

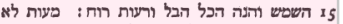

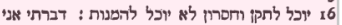

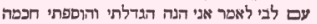

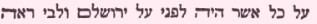

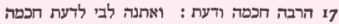

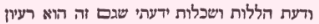

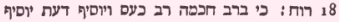
טכאוב 18

$166,172,173,176,188_{1} 191,196,21 i, 212,213,218 ; 224,226$ i $227,228,231,239,240,245,252,253,260,275,384,680,693$. ריה $2^{\circ}, 157-17$. . $31,93,110,119,141,177,210$,

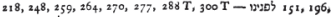
199 - ו 145 . 14.

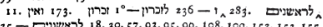

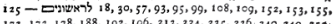
$172,173,178,188,192,196,213,224,235,236,240,249,252$.

Bible

\section{Introduction}

Qohelet

Kennicott's work

Digitalization

Optical character

recognition

The Context-free Grammar

The Visitor

TEl encoding

Reference text: edition of Ev. van der Hooght (1710) 


\section{Qohelet according to Kennicott}

A Rule-Based

Parsing System

for Encoding

Kennicott's

Collation

L I B E R E C C L E S I A S T E.

of the Hebrew

\section{A $\mathbf{P}$ U $\mathbf{T}$ I.}

דברי קהלת בן דוד מלך בירושלם:

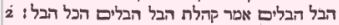

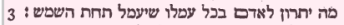

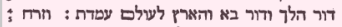

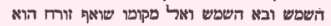

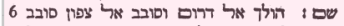

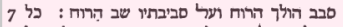

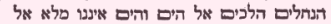

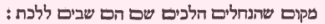

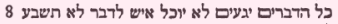

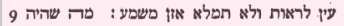

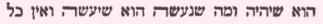

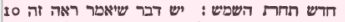

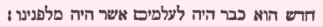

\section{VARIAS LECTIONES.}

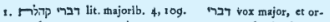
nata, 136, 139- non major; 1, 2, 3, 14, 31, 57, 67, 82, 89, 93, $99,100,110,119,128,130,141,144,231,237,239,270,289$. בירושלים ש 57, 57, 121. $107,109,152$ - fup. raf. $139-6$ - 76.

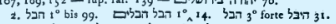

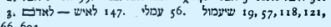
166,693 .
1ג 12 12 13 לדרוש ולתור בחכטה על כל אשר נעשה תחת למים

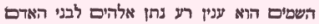

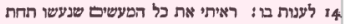

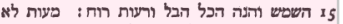

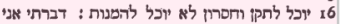

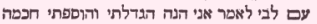

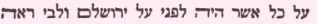

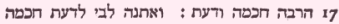

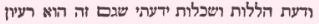

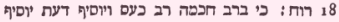
טכאטר 18

$166,172,173,176,188,191,196,21 i, 212,213,218,224,226$; $227,228,23 x, 239,240,245,252,253,260,275,384,680,693$. הר $2^{\circ}, 157-17$. 17 . $31,93,110,119,141,177,210$, $218,248,259,264,270,277,288 \mathrm{~T}, 300 \mathrm{~T}-1006{ }_{151}, 196$, 199 - מ 145 . 14.

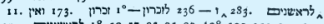
125 - $172,173,178,188,192,196,213,224,235,236,240,249,252$.

- Reference text: edition of Ev. van der Hooght (1710)

> Critical apparatus: 350 witnesses and ca. 2600 variants

Introduction

Qohelet

Kennicott's work

Digitalization

Optical character

recognition

The Context-free Grammar

The Visitor

TEl encoding 


\section{Digitalizing Kennicott's collation}

Digitalization can provide useful information for:

A Rule-Based

Parsing System

for Encoding

Kennicott's

Collation

of the Hebrew

Bible

- Textual history and philology

- Computing genealogical relationships (stemmatology)

[Hempel, Goshen-Gottstein, Gese, Sacchi, Borbone]

- Studying the phenomenology of the copying process (scribal habits, genesis of common copying errors...)

- Codicology and paleography

- Classifying mss according to ethno-geographic criteria (Ashkenazic/Sephardic/Italian mss...)

[Penkower 1988, 2002]

- Linguistics

- usus scribendi (scriptio plena/defectiva, orthography...)

[Cohen 1986] 


\section{Digitalizing Kennicott's collation}

A Rule-Based

Parsing System

for Encoding

Kennicott's

Collation

of the Hebrew

Bible

In order to permit the computer to extract information from the critical apparatus, data need to be not only machine readable, but also fully machine actionable

Machine readability is achievied through OCR technology (digitization)

Machine actionability is ensured by textual encoding through markup languages (XML) 


\section{Towards an automated encoding}

- Manually encoding critical apparatus is expensive, time-consuming and error-prone

- It is possible to encode automatically through Natural Language Processing (NLP) tools

- There are two main approaches:

1. Rule-based systems:

- Rules for describing the language are defined by the user

- Robust, but the language needs to be as structured as possible

- Relatively simple

2. Machine learning systems:

- Rules for describing the language are derived from the data (machine learning algorithms)

- More efficient for non- or semi-structured languages

- Complex 


\section{The language of Kennicott's apparatus}

- Well structured

- Textual phenomena are expressed in a non-redundant and unambigous way by means of:

1. Conventional vocabulary: set of finite symbols (numbers, strings, abbreviations)

2. Rigorous syntax: the position of apparatus components conveys information about their function

A Rule-Based

Parsing System

for Encoding

Kennicott's

Collation

of the Hebrew

Bible

Digitalization

Optical character

recognition

The Context-free Grammar

The Visitor

TEl encoding 


\section{Parsing the critical apparatus}

An example from Qoh. 1:1

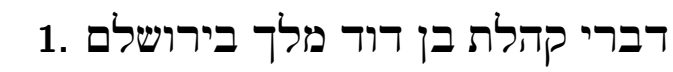

Words of Qohelet, son of David king in Jerusalem

Kennicott's apparatus

1. lit. majorib. 4, 109.

121.

57, 100, 260 ; forte 141.

76 יהורה בירושלים - 107, 109, 152 - sup. ras. 139 בירושלים.

A Rule-Based

Parsing System

for Encoding

Kennicott's

Collation

of the Hebrew

Bible

Digitalization

Optical character

recognition

The Context-free Grammar

The Visitor

TEI encoding 


\section{Apparatus components}

A Rule-Based Parsing System for Encoding Kennicott's Collation of the Hebrew Bible

\section{1. דברי קהלת בן דוד מלך בירושלם}

1. רברי קהלת lit. majorib. 4, 109.

121.

57, 100, 260 ; forte 141.

76 יהורה בירושלים - 107, 109, 152 - sup. ras. 139 בירושלים. 


\section{Apparatus components}

A Rule-Based Parsing System for Encoding

Kennicott's

Collation

of the Hebrew

Bible

\section{1. דברי קהלת בן דוד מלך בירושלם}

Digitalization

Optical character

recognition

1. lit. majorib. 4, 109.

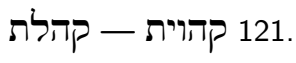

57, 100, 260 ; forte 141.

76 יהורה בירושלים - 107, 109, 152 - sup. ras. 139 בירושלים.

variation place (number of chapter and verse) 


\section{Apparatus components}

A Rule-Based Parsing System for Encoding Kennicott's Collation of the Hebrew Bible

\section{1. דברי קהלת בן דוד מלך בירושלם}

1. רברי קהלת lit. majorib. 4, 109.

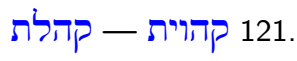

57, 100, 260 ; forte 141.

76 יהורה בירושלים - 107, 109, 152 - sup. ras. 139 בירושלים.

\section{readings}




\title{
Apparatus components
}

A Rule-Based Parsing System for Encoding Kennicott's

Collation

of the Hebrew Bible

\section{1. דברי קהלת בן דוד מלך בירושלם}

Introduction

Qohelet

Kennicott's work

Digitalization

Optical character

recognition

1. רברי קהלת lit. majorib. 4, 109.

The Context-free Grammar 121.

141.

76 יהודה בירושלים - 107, 109, 152 - sup. ras. 139 בירושלים.

\author{
witnesses sigla
}




\section{Apparatus components}

A Rule-Based Parsing System for Encoding Kennicott's Collation of the Hebrew Bible

\section{1. דברי קהלת בן דוד מלך בירושלם}

Introduction

Qohelet

Kennicott's work

Digitalization

Optical character

recognition

1. רברי קהלת lit. majorib. 4, 109.

The Context-free Grammar 121.

141.

76 יהודה בירושלים - 107, 109, 152 - sup. ras. 139.

variant description (primo, nunc, forte etc.) 


\section{Apparatus components}

A Rule-Based Parsing System for Encoding Kennicott's

Collation

of the Hebrew Bible

\section{1. דברי קהלת בן דוד מלך בירושלם}

Introduction

Qohelet

Kennicott's work

Digitalization

Optical character

recognition

1. רברי קהלת lit. majorib. 4, 109 .

The Context-free Grammar

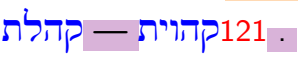

TEl encoding

. 57 דויר ; forte 141.

76יהודה בירושלים - sup. ras. 139 - 152, 109 בירושלים.

separators 


\section{Apparatus components}

A Rule-Based Parsing System for Encoding Kennicott's

Collation

of the Hebrew Bible

\section{1. דברי קהלת בן דוד מלך בירושלם}

1. דברי קהלת lit. majorib. 4,109.

121.

57, 100,260; forte 141.

76יהורה בירושלים - sup. ras. 139 - 152, 109, 107 בירושלים.

lemma (reading from the reference text) 


\section{Apparatus components}

A Rule-Based

Parsing System

for Encoding

Kennicott's

Collation

of the Hebrew

Bible

\section{1. דברי קהלת בן דוד מלך בירושלם}

Digitalization

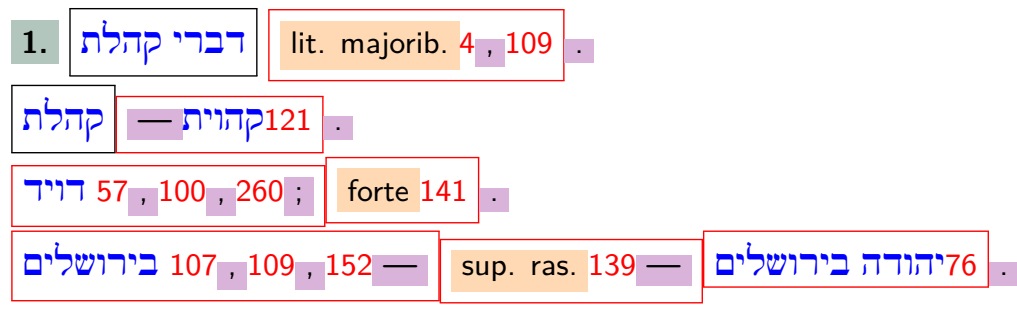

Optical character recognition

The Context-free Grammar The Visitor

TEl encoding

variant readings diverging from the lemma 


\section{Apparatus components}

A Rule-Based

Parsing System

for Encoding

Kennicott's

Collation

of the Hebrew

Bible

\section{1. רברי קהלת בן דוד מלך בירושלם}

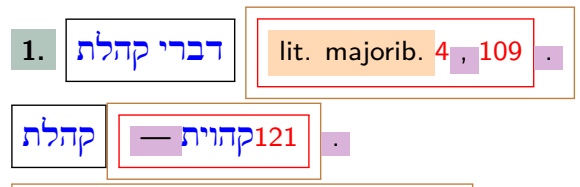

Digitalization

Optical character

recognition

The Context-free Grammar

The Visitor

TEl encoding

\begin{tabular}{|l|l|}
\hline $757,100,260 ;$ & forte 141 \\
\hline
\end{tabular}

152 , 109 , 107 בירושלים

sup. ras. 139 -

76ייהודה בירושלים

\section{reading groups}




\section{Apparatus components}

\section{1. דברי קהלת בן דוד מלך בירושלם}

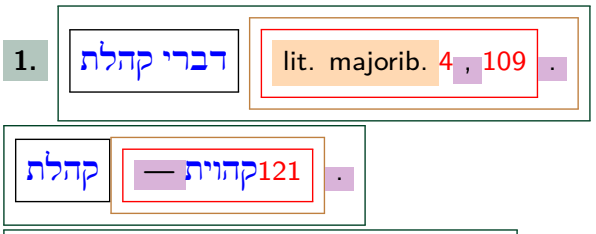

A Rule-Based

Parsing System

for Encoding

Kennicott's

Collation

of the Hebrew Bible

Introduction

Qohelet

Kennicott's work

Digitalization

Optical character

recognition

The Context-free Grammar

The Visitor

TEl encoding

\begin{tabular}{|l|l|}
\hline $57,100,260 ;$ & forte 141. \\
\hline
\end{tabular}

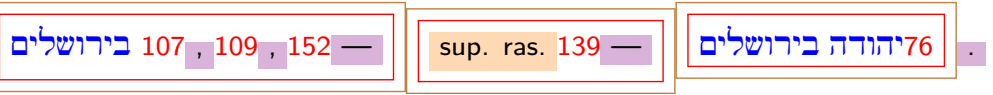




\section{A rule-based parsing system}

A Rule-Based

Parsing System

for Encoding

Kennicott's

Collation

of the Hebrew

Bible

- It is possible to exploit the nature of structured language characterizing Kennicott's apparatus in order to perform an automated encoding

- The machine is instructed on how to recognize the apparatus components through a parser

- A parser is a software that analyses sequences of strings (parsing) according to given rules (rule-based) 


\section{A rule-based parsing system: pipeline}

1. The apparatus is processed through OCR technology to make it machine readable

2. A context-free grammar (CFG) is built to describe the language of the apparatus

3. A Visitor is implemented to produce $X M L$ code

4. XSL-T stylesheets convert XML to TEI

A Rule-Based

Parsing System

for Encoding

Kennicott's

Collation

of the Hebrew

Bible

Digitalization

Optical character

recognition

The Context-free Grammar

The Visitor

TEl encoding 


\section{A rule-based parsing system: pipeline}

1. The apparatus is processed through OCR technology to make it machine readable

2. A context-free grammar (CFG) is built to describe the language of the apparatus

3. A Visitor is implemented to produce $X M L$ code

4. XSL-T stylesheets convert XML to TEI

ANTLR 4 (ANother Tool for Language Recognition)

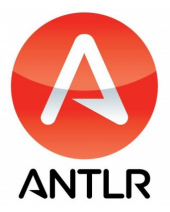

https://www.antlr.org/ 


\section{Optical character recognition}

A Rule-Based

Parsing System for Encoding

Kennicott's

Collation

of the Hebrew

Bible

- Data are converted to machine readable format (.txt) through Tesseract (https://github.com/tesseract-ocr/tesseract)

- The output is corrected by hand

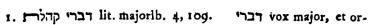
nata ; 136, 139- non major: 1, 2, 3, 14, 31, 57, 67, 82, 89, 93, 99, 100, $110,119,128,130,141,144,231,237,239,270,289$. בירושלים 107, 109, 152 - fup. raf. $139-6$ - 76.

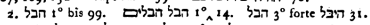

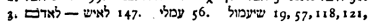
166,693 .

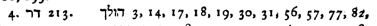
$89,93,95,99,109,110,117,118,125,129,152,153,155,158$, $164,166,167,170,172,173,175,176,177,187,188,196,211$, $212,213,218,224,227,235,237,239,244,249,252,253,259$, 270, 384, 674,680,693; primo 171; forte 94,128. לעy 57. עומדת 1, 2, 4, 14, 30, 50, 57, 67, 77, 83, 93, 95, 99, 109, 110, $117,118,125,128,129,136,139,144,152,153,164,166$, $172,173,175,181,187,196,211,212,213,214,224,226,227$, $228,236,237,244,245,252,253,270,680,693$.

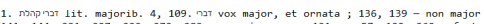
$141,144,231,237,239,270,289 . \quad$. 2. הבר $11^{\circ}$ bis 99 .

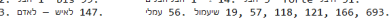
4. 7 213. T) $3,14,17,18,19,30,31,56,57,77,82,89,93,95,99$, $172,173,175,176,177,187,188,196,211,212,213,218,224,227,235,237$,

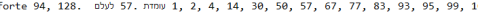
$172,173,175,181,187,196,211,212,213,214,224,226,227,228,236,237$,

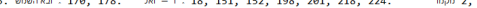
$223,231,384$. ๆNש $2,3,17,77,89,111,118,121,151,152,155,157,158,1$ $111,121,129,158,172,187,213,218,223,224,236,237,239,244$ - กาा 240. 6. $117,141,166,187,212,213,223,231,239,240,244,248,253,260$. 121, $166,167,172,196,211,218,224,235,237,252,384$; primo $4 . \quad 2^{\circ}$

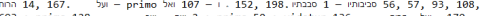

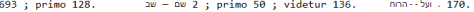
7. $1^{\circ}$ - הלכים $2,4,17,56,77,95,99,111,121,125,129,150,152,155$,

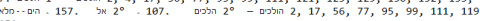
151.

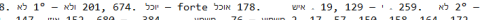

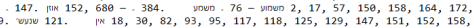

Introduction

Qohelet

Kennicott's work

Digitalization

Optical character recognition

The Context-free Grammar The Visitor

TEl encoding 


\section{The Context-free grammar}

A Rule-Based

Parsing System

for Encoding

Kennicott's

Collation

of the Hebrew

Bible

- The Context-free grammar (CFG) is a formal grammar consisting of a set of top-down, rewriting rules

- The rules of a CFG describe a formal language

- A lexer and a parser are implemented in ANTLR4 on the base of the CFG

- The lexer tokenizes the formal language (tokenization rules)

- The parser checks its syntax (parser rules) creating an Abstract Syntactic Tree (AST) 


\section{The Context-free grammar}

The readings

lit. majorib. 4, 109.

A Rule-Based Parsing System for Encoding Kennicott's

Collation

of the Hebrew Bible

ntroduction

Qohelet

Kennicott's work

Digitalization

Optical character

recognition

The Context-free Grammar The Visitor

TEl encoding 


\section{The Context-free grammar}

\section{The readings}

רברי קהלת lit. majorib. 4, 109.

A Rule-Based

Parsing System

for Encoding

Kennicott's

Collation

of the Hebrew Bible

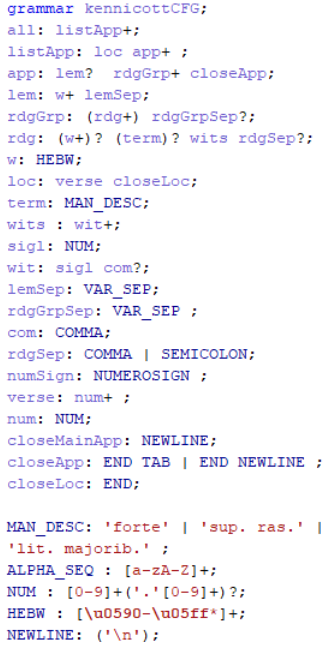




\section{The Context-free grammar}

\section{The readings}

דברי קהלת lit. majorib. 4, 109.

A Rule-Based

Parsing System

for Encoding

Kennicott's

Collation

of the Hebrew Bible

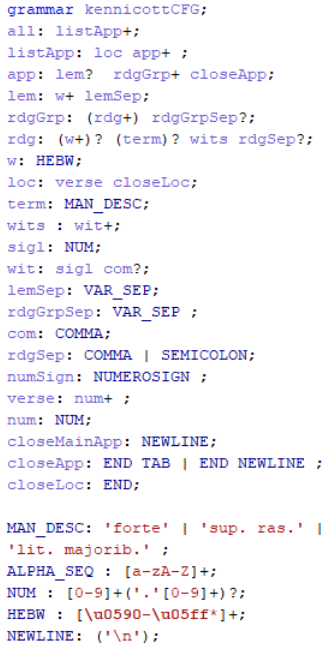

Qohelet

Kennicott's work

Digitalization

Optical character

recognition

The Context-free Grammar The Visitor

TEl encoding 


\section{The Context-free grammar}

The reading groups

76 יהורה בירושלים - 107, 109, 152 - sup. ras. 139 בירושלים.

A Rule-Based Parsing System for Encoding Kennicott's

Collation

of the Hebrew Bible

ntroduction

Qohelet

Kennicott's work

Digitalization

Optical character

recognition

The Context-free Grammar The Visitor

TEl encoding 


\section{The Context-free grammar}

\section{The reading groups}

76 יהורה בירושלים - 107, 109, 152 - sup. ras. 139 בירושלים.

A Rule-Based

Parsing System for Encoding

Kennicott's

Collation

of the Hebrew

Bible
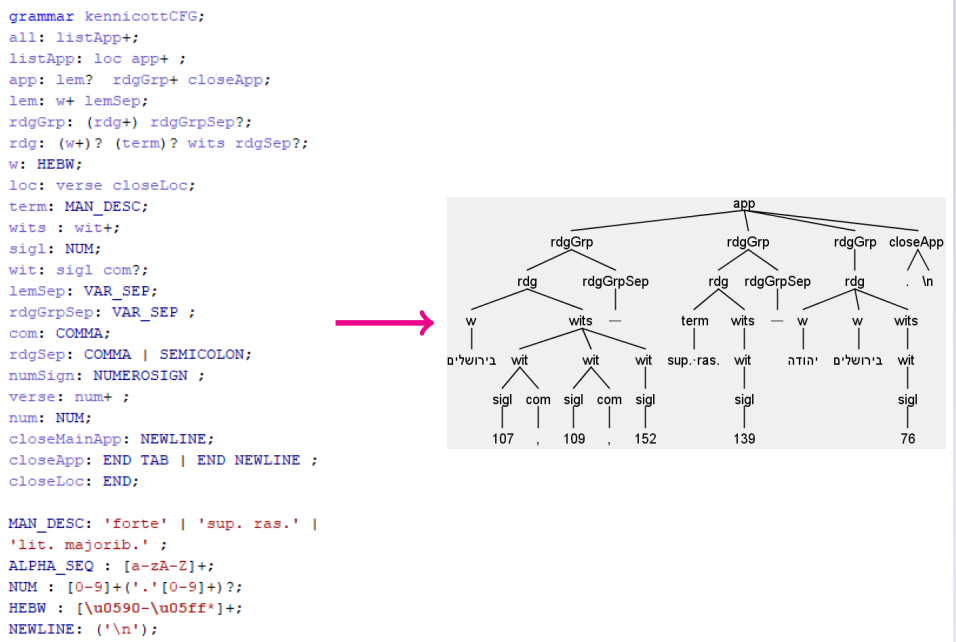

\section{Introduction}

Qohelet

Kennicott's work

Digitalization

Optical character

recognition

The Context-free Grammar The Visitor 


\section{The Context-free grammar}

\section{The apparatus entry}

1. 1it. majorib. 4, 109. 5ברי קהלי 121, 100, 260 ; forte 141. בירושלים. 107, 109, 152 - sup.

ras. 139 - יהודה בירושלים 76.

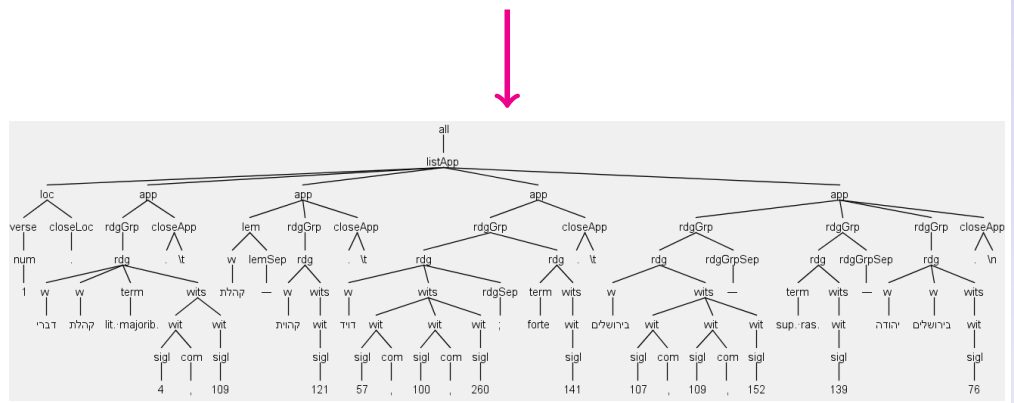

A Rule-Based

Parsing System for Encoding

Kennicott's

Collation

of the Hebrew

Bible

\section{Introduction}

Qohelet

Kennicott's work

Digitalization

Optical character.

recognition

The Context-free Grammar

The Visitor

TEl encoding

Stemmatic analysis 


\section{The Visitor}

A Rule-Based

Parsing System

for Encoding

Kennicott's

Collation

of the Hebrew

Bible

- The Visitor is a tree-walking mechanism

- In this implementation, the Visitor traverses the tree and slavishly translates the CFG rules into XML nodes

- It is a general-purpose exporter: once implemented, it can be applied to every CFG without further customization 


\section{The Visitor}

A Rule-Based

Parsing System

for Encoding

Kennicott's

Collation

of the Hebrew

Bible

- The Visitor is a tree-walking mechanism

- In this implementation, the Visitor traverses the tree and slavishly translates the CFG rules into XML nodes

- It is a general-purpose exporter: once implemented, it can be applied to every CFG without further customization

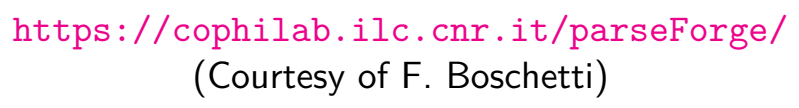




\section{The Visitor: from the AST to $\mathrm{XML}$}

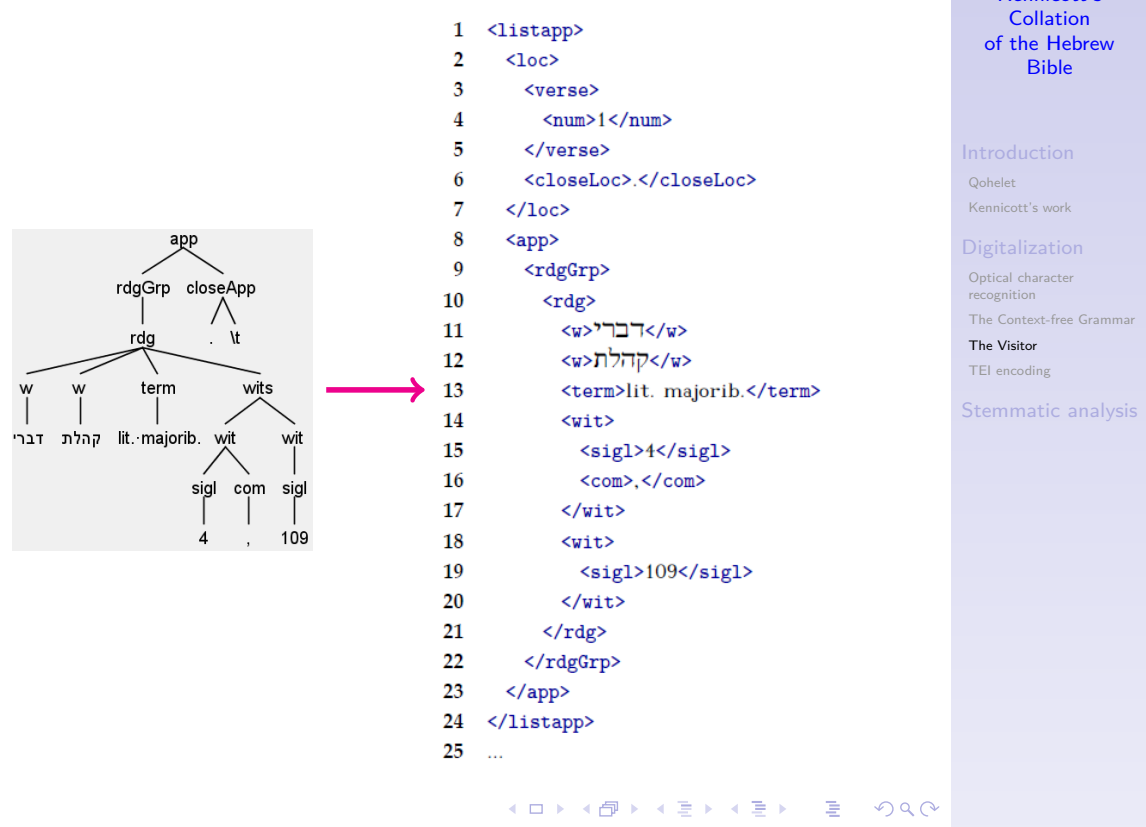




\section{XSL-T: from XML to TEI}

\section{Location referenced method}

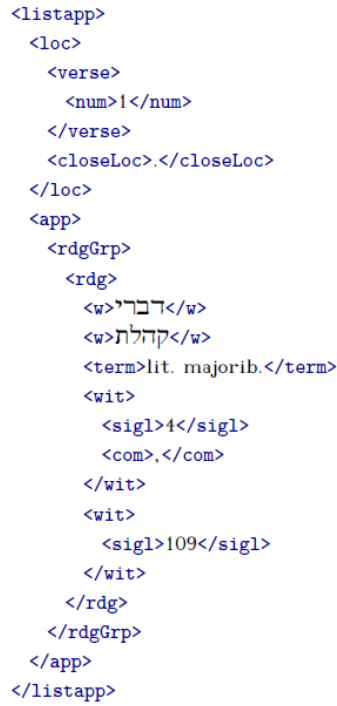

A Rule-Based Parsing System for Encoding Kennicott's Collation of the Hebrew Bible

$1<$ listapp>

2 <app loc="1 1">

$3<\mathrm{lem}>$

$4<$ < $>$ >

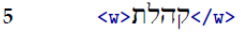

$6</$ lem $>$

$7 \quad<$ dgGrp $>$

$8 \quad<$ rdg wit="\#K4 \#K109">

$9<$ <erm $>$ lit. majorib. $</$ term $>$

$10</$ rdg $>$

$11</$ rdgGrp $>$

$12</ a p p>$

$13<$ <app loc="1 1">

$14<$ lem>

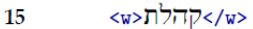

$16</$ lem $>$

$17<$ rdgGrp $>$

$18<$ rdg wit="\#K121">

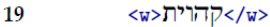

$20</ \mathrm{rdg}>$

$21</$ rdgGrp $>$

$22</$ app $>$ 


\section{A rule-based parser}

A Rule-Based Parsing System for Encoding Kennicott's

Collation

of the Hebrew Bible

\section{Results}

1. $100 \%$ of accuracy for Qohelet 


\section{A rule-based parser}

A Rule-Based Parsing System for Encoding

Kennicott's

Collation

of the Hebrew

Bible

\section{Results}

1. $100 \%$ of accuracy for Qohelet

2. 2617 variants correctly parsed and encoded 


\section{A rule-based parser}

A Rule-Based

Parsing System

for Encoding

Kennicott's

Collation

of the Hebrew

Bible

\section{Results}

1. $100 \%$ of accuracy for Qohelet

2. 2617 variants correctly parsed and encoded

3. Rut (1025 variants) and Song of Songs (1238): few syntactic errors ( $99 \%$ accuracy) 


\section{A rule-based parser}

A Rule-Based

Parsing System

for Encoding

Kennicott's

Collation

of the Hebrew

Bible

\section{Results}

1. $100 \%$ of accuracy for Qohelet

2. 2617 variants correctly parsed and encoded

3. Rut (1025 variants) and Song of Songs (1238): few syntactic errors (99\% accuracy)

4. The CFG is extended in order to include unseen textual phenomena ( $100 \%$ accuracy) 


\section{A rule-based parser}

A Rule-Based

Parsing System

for Encoding

Kennicott's

Collation

of the Hebrew

Evaluation

Bible

The system is robust

- Other biblical books of Kennicott's collection can be encoded 


\section{A rule-based parser}

A Rule-Based

Parsing System

for Encoding

Kennicott's

Collation

Evaluation

of the Hebrew

Bible

$>$ The system is robust

- Other biblical books of Kennicott's collection can be encoded

- A parser approach is faster than manual encoding

It is possible to export data in different formats (XML, HTML, relational databases, LTEXetc.)

- It is less error prone: the CFG provides a spell-checking system, useful for detecting

1. errors generated after OCR (transcriptional errors)

2. inconsistencies in the printed source

Tighter control on semantic errors when exporting to XML-TEl 


\section{Treatment of residuals}

- Kennicott's apparatus minimizes natural language

- Encoding by means of concise and standard annotations

A Rule-Based Parsing System for Encoding Kennicott's

Collation of the Hebrew Bible 


\section{Treatment of residuals}

- Kennicott's apparatus minimizes natural language

Encoding by means of concise and standard annotations

- Exceptions (residuals):

- 7:29 "Incipit cap. 8 a voce חכפת "מש, medio commatis..."

- 11:9 - post hanc vocem sequitur Psal. 102..."

A Rule-Based Parsing System for Encoding

Kennicott's

Collation

of the Hebrew Bible

ntroduction

Qohelet

Kennicott's work

Digitalization

Optical character recognition

The Context-free Grammar The Visitor

TEl encoding 


\section{Treatment of residuals}

- Kennicott's apparatus minimizes natural language

- Encoding by means of concise and standard annotations

- Exceptions (residuals):

- 7:29 "Incipit cap. 8 a voce חכממת, medio commatis..."

- 11:9 - post hanc vocem sequitur Psal. 102..."

Residuals are treated as unprocessed/unstructured data:

- Correctly identified (no syntactic errors)

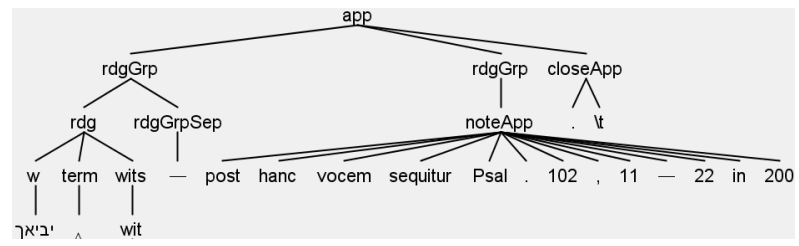

Stored in note-like XML elements 


\section{Stemmatic analysis}

A Rule-Based

Parsing System for Encoding Kennicott's

Collation

of the Hebrew

Bible

Introduction

Qohelet

Kennicott's work

Digitalization

Optical character

recognition

The Context-free Grammar

The Visitor

TEl encoding

Stemmatic analysis 


\section{Stemmatic analysis}

A Rule-Based

Parsing System for Encoding

Kennicott's

Collation

of the Hebrew

Bible

- Encoding can be used for quantitative analysis (e. g. computer-assisted stemmatology)

Introduction

Qohelet

Kennicott's work

Digitalization

Optical character

recognition

The Context-free Grammar

The Visitor

TEl encoding

Stemmatic analysis 


\section{Stemmatic analysis}

A Rule-Based

Parsing System

for Encoding

Kennicott's

Collation

of the Hebrew

Bible

- Encoding can be used for quantitative analysis (e. g. computer-assisted stemmatology)

- Few attempts to study the medieval tradition of the Hebrew Bible according to (neo-)Lachmannian criteria

- Mss are treated singularly, not as groups or families

- A stemmatic classification of medieval mss is still missing 


\section{From XML-TEI to data matrix}

In order to permit the computer to compute genealogical relationships, it is necessary to transform philological data into a numerical format (data matrix)

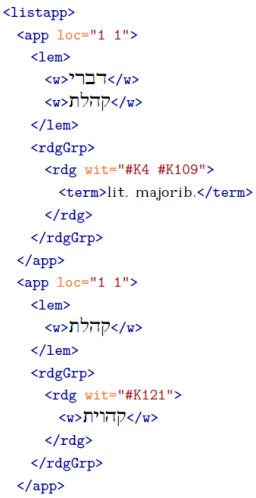




\section{From XML-TEI to data matrix}

\section{In order to permit the computer to compute genealogical relationships, it is necessary to transform philological data into a numerical format (data matrix)}

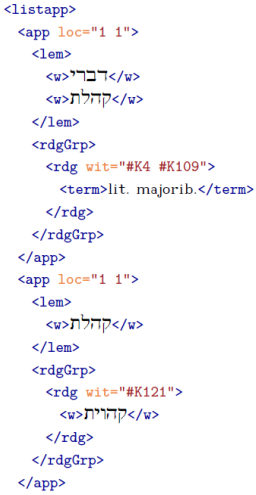

\begin{tabular}{|c|c|}
\hline & 1 \\
\hline xon & 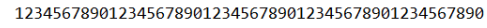 \\
\hline EK & 00000000000000000000000000000000000000000000 \\
\hline $00 \mathrm{~L}$ & 000000000000000000000000000000000000000000000000000 \\
\hline 3IAK1 & 00000000000000010001000000000000000010000000001000 \\
\hline $3 S K 2$ & 00001000000100000010000000000000000000000000000000 \\
\hline 4 SK3 & 00000000000000000000000000100000000000000000000000 \\
\hline $2 \mathrm{AK} 4$ & 0000010100000000000000100000000000010000000 \\
\hline 4SK14 & 0010000000000000001000000000000000 \\
\hline 3AK17 & 000001000001000000010010000000000 \\
\hline 3АК18 & 010000100001000010011010000000010 \\
\hline 4SK19 & 000000 \\
\hline $2 A K 30$ & 00000010001000000100001000000000000000000000000010 \\
\hline $00 \mathrm{~K} 31$ & 00000000000000000001000000000000000000000000000000 \\
\hline $3 \mathrm{AK} 50$ & 00001000000000000000000000000000000000000000000000 \\
\hline $3 \mathrm{AK} 56$ & 00000000000000000010000001000000000110100000000000 \\
\hline 4 SK67 & 0000000000000000000000000000000000000000000 \\
\hline $2 A K 76$ & 0000000100000000000000106 \\
\hline 2 AK77 & 0001010000001001 \\
\hline $2 \mathrm{AK} 80$ & 000000000000000000000000000 \\
\hline $35 K 82$ & 10000000000001001000000000000100000000000000 \\
\hline $35 K 83$ & 00000000000000000000000000000000000000000000000000 \\
\hline $35 K 89$ & 00000000000000000000001000000000000000000000000000 \\
\hline ЗАК93 & 00000010000000000001001000000000000100000000000000 \\
\hline 2IK94 & 00000000000000000000000000000000000000000000000000 \\
\hline & 00000110000000000001010000000000010100100000000000 \\
\hline & 00000000000000000001001000000000 \\
\hline 3SK100 & 0000000000010000000000000000000000000000000000000 \\
\hline
\end{tabular}

A Rule-Based Parsing System for Encoding Kennicott's Collation of the Hebrew Bible

Introduction Qohelet

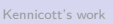

Digitalization Optical character recognition

The Context-free Grammar The Visitor TEl encoding

Stemmatic analysis 


\section{Data matrix: regularization}

A Rule-Based Parsing System for Encoding

Kennicott's

Collation

of the Hebrew

Bible

Elimination of

> Partially collated witnesses

> Accidentals (e. g. orthographic variants)

- Marginalia, dubious and second hand variants

Total: 119 witnesses and 371 variants 


\section{Phylogenetic analysis}

- The data matrix is analysed by phylogenetic algorithms, which produce tree-like graphs (phylograms) representing paths of textual evolution

- Many phylogenetic algorithms: Maximum Parsimony

- Implemented in PAUP software

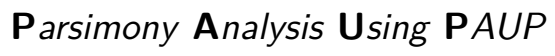

A Rule-Based

Parsing System

for Encoding

Kennicott's

Collation

of the Hebrew

Bible
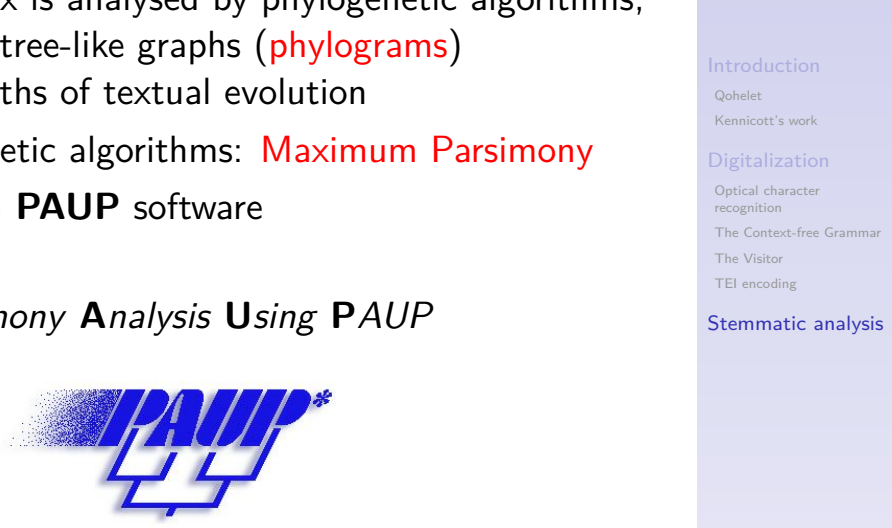

http://paup.phylosolutions.com/ 


\section{Strict consensus tree}

\section{Consensus of more than 25.000 equally parsimonious trees}

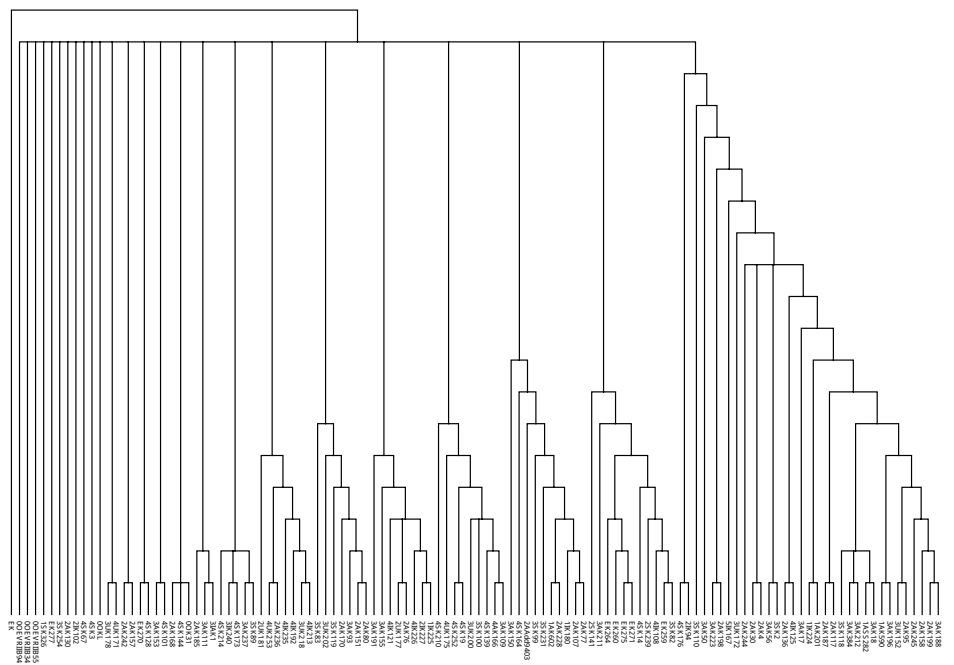

A Rule-Based Parsing System for Encoding Kennicott's Collation of the Hebrew Bible

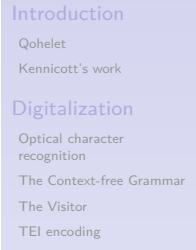

Stemmatic analysis 


\section{Strict consensus tree}

\section{Consensus of more than 25.000 equally parsimonious trees}

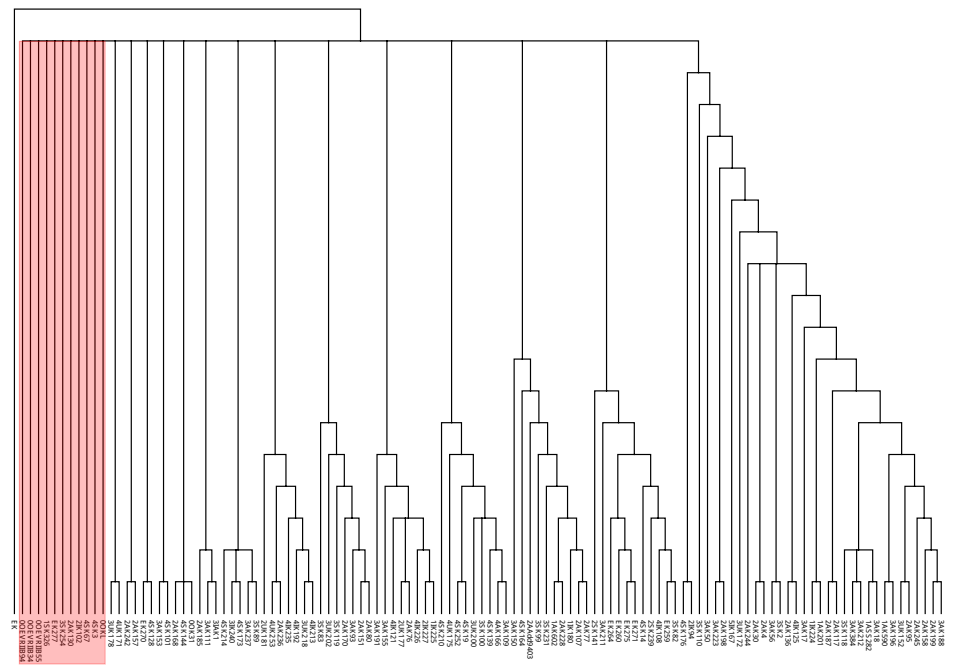

A Rule-Based Parsing System for Encoding Kennicott's Collation of the Hebrew Bible

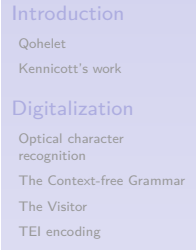

Stemmatic analysis 


\section{Strict consensus tree}

\section{Consensus of more than 25.000 equally parsimonious trees}

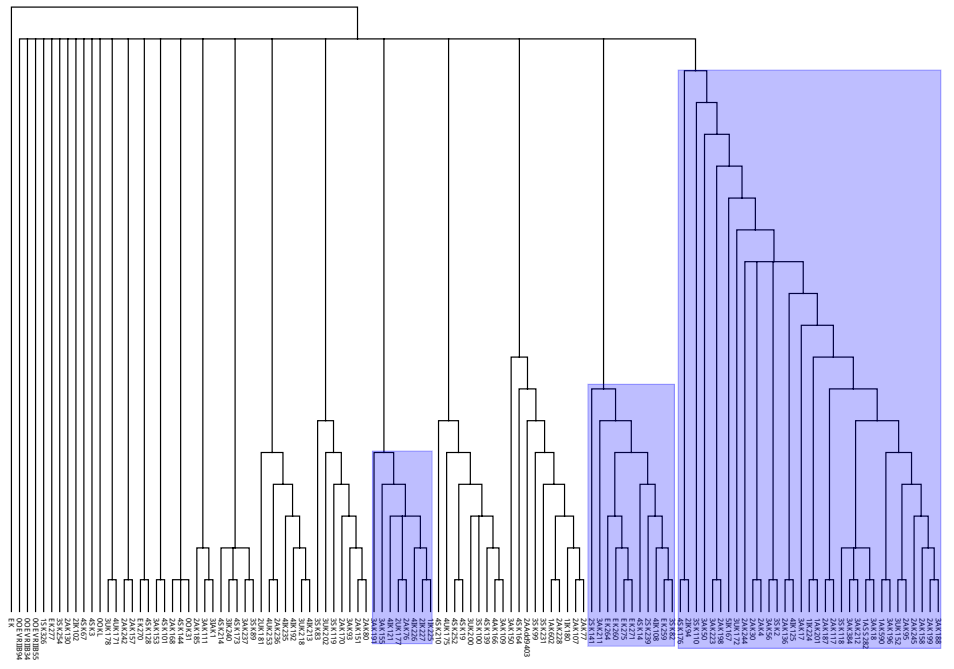

A Rule-Based Parsing System for Encoding Kennicott's Collation of the Hebrew Bible

\section{Introduction} Qohelet

Kennicott's work

Digitalization

Optical character

recognition

The Context-free Grammar The Visitor

TEl encoding

Stemmatic analysis 


\section{Phylogenetic methods and biblical mss}

> Groups are identified according to ancestral variants

> Some groups have characteristic variants

A Rule-Based

Parsing System

for Encoding

Kennicott's

Collation

of the Hebrew

Bible

- Corroborated by external criteria

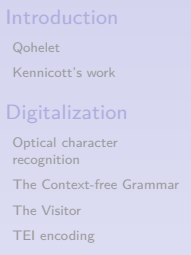

Stemmatic analysis 


\section{Phylogenetic methods and biblical mss}

> Groups are identified according to ancestral variants

> Some groups have characteristic variants

> Corroborated by external criteria

\section{Limits}

$\checkmark$ Important mss are missing

- Variants concern consonantal text only

> Most are polygenetic

> Contamination

A Rule-Based Parsing System for Encoding

Kennicott's

Collation

of the Hebrew Bible

Introduction

Qohelet

Kennicott's work

Digitalization

Optical character

recognition

The Context-free Grammar

The Visitor

TEl encoding

Stemmatic analysis 


\section{Phylogenetic methods and biblical mss}

- Groups are identified according to ancestral variants

> Some groups have characteristic variants

A Rule-Based

Parsing System

for Encoding

Kennicott's

Collation

of the Hebrew

Bible

- Corroborated by external criteria

\section{Limits}

- Important mss are missing

- Variants concern consonantal text only

> Most are polygenetic

> Contamination

\section{Future works}

- More data:

- more mss

- punctuation, Massora, para-textual variants

- Variants can be weighted and ordered 


\section{Bibliographical references}

Barthélemy, D. (1992). Les manuscrits médiévaux et le texte tibérien classique. In Critique textuelle de l'Ancien Testament, 3. Ézéchiel, Daniel et les 12 Prophètes, Volume 3 of Orbis Biblicus et Orientalis, pp. xix-xcvi. Fribourg/Göttingen: Éditions Universitaires/Vandenhoeck \& Ruprecht.

Borbone, P. G. (1990). Il libro del profeta Osea. Edizione critica del testo ebraico. Torino: Zamorani.

Cohen, M. (1973). מגבשי כתיב במצחפי מסורה עתיקים ומשמעם לתולדות נוסח המקרא המקובל. Ph. D. thesis, Hebrew University, Jerusalem. [Unpublished].

Cohen, M. (1979). האידיאה בדבר קדושת הנוסח לאותיותיו וביקורת הטכסט. In S. Uriel (Ed.), המקרא ואנחיר, Volume 1, pp. 42-69. Tel Aviv: רביר / Dvir.

Cohen, M. (1980). עיוני מקרא ופרשנות .קווי יסוד לדמותו העיצורית של הטקסט בכתבי יד מקראיים מיפי הביניים Studies in Bible and Exegesis 1, 123-182.

Cohen, M. (1981). לדמותם הקונסונאנטית של דפוסי המקרא הראשונים: המהרורה הראשונה של התנ"ך השלם - דפוס 1488 / The Consonantal Character of the First Rabbinic Printings: the Editio Princeps of the Entire Bible Soncino 1488. In ספר השנה של אוניברסיטת בר־-אילן, Volume XVIII-XIX, pp. 47-67. Ramat Gan: University Press.

Cohen, M. (1986). מהו 'נוסח המסורה', ומה היקף אחיזתו בתולדות המסירה של ימה" / The 'Masoretic Text' and the Extent of Its Influence on the Transmission of the Biblical Text in the Middle Ages. In S. Uriel (Ed.), עיוני מקרא / וברשנות / Studies in Bible and Exegesis, Volume 2, pp. 229-256. Ramat Gan: Bar Ilan University Press.

Gese, H. (1957). Die hebräischen Bibelhandschriften zum Dodekapropheton nach der Variantensammlung des Kennicott. Zeitschrift für die Alttestamentliche Wissenschaft 69(1-4), 55.

Goshen-Gottstein, M. H. (1954). Die Jesaiah-Rolle und das Problem der hebräischen Bibelhandschriften. Biblica 35(4), $429-442$.

Hempel, J. (1930). Chronik. Zeitschrift für die Alttestamentliche Wissenschaft 48, 187-206.

Hempel, J. (1934). Innermasoretische Bestätigungen des Samaritanus. Zeitschrift für die Alttestamentliche Wissenschaft 52(1), 254-274.

Penkower, J. S. (1982). יעקב בן חיים וצמיחת מהדורת המקראות הנדולות / Jacob Ben-Hayyim and the Rise of the Biblia Rabbinica. Ph. D. thesis, Hebrew University, Jerusalem. [Unpublished].

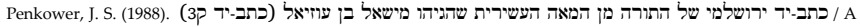

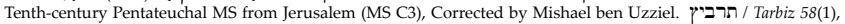
49-74.

Penkower, J. S. (2002). A Sheet of Parchment from a 10th or 11th Century Torah Scroll: Determining Its Type Among Four Traditions (Oriental, Sefardi, Ashkenazi, Yemenite). Textus 21(1), 235-264.

Sacchi, P. (1973). Analisi quantitativa della tradizione medievale del testo ebraico della Bibbia secondo le collazioni del De Rossi. Oriens Antiquus 12, 1-13. Wevers, J. W. (1948). A Study in the Hebrew Variants in the Books of Kings. Zeitschrift für die Alttestamentliche Wis-
senschaft $61(1), 43$.
A Rule-Based

Parsing System

for Encoding

Kennicott's

Collation

of the Hebrew

Bible

\section{Introduction}

Qohelet

Kennicott's work

Digitalization

Optical character

recognition

The Context-free Grammar

The Visitor

TEl encoding

Stemmatic analysis 